\title{
A MULTIMENSIONALIDADE DAS PESQUISAS EM EDUCAÇÃO DE JOVENS E ADULTOS: O ESTADO DO CONHECIMENTO EM PERIÓDICOS DO NORDESTE
}

\author{
THE MULTIMENSIONALITY OF RESEARCH IN YOUTH AND ADULT EDUCATION: THE STATE OF \\ KNOWLEDGE IN NORTHEASTERN JOURNALS
}

\section{LA MULTIMENSIONALIDAD DE LA INVESTIGACIÓN EN EDUCACIÓN DE JÓVENES Y ADULTOS: EL ESTADO DEL CONOCIMIENTO EN REVISTAS DEL NORESTE}

\author{
Adenilson Souza Cunha Júnior ${ }^{1}$ \\ Geovânia Lúcia dos Santos² \\ Marileide Moutinho Pamponet Lima ${ }^{3}$
}

\begin{abstract}
Resumo: $\mathrm{O}$ artigo apresenta o mapeamento das produções acadêmicas no campo da Educação de Jovens e Adultos (EJA) publicadas nos periódicos Revista Tempos e Espaços em Educação e Revista Práxis Educacional. Utilizando o Estado da Arte como caminho metodológico, foram inventariados, inicialmente, quarenta e cinco artigos que discutem temas relacionados a EJA durante todo período de existência dos dois periódicos. Considerando que a maior recorrência das produções se concentrou no descritor formação de professores para atuar na EJA, aplicamos um recorte temporal entre 2010-2020 para analisar mais detalhadamente os artigos voltados para essa temática. Os resultados deste levantamento apontam que as produções na área de EJA são multidimensionais, com maior destaque para área de formação de professores, que segue sendo uma temática fundamental para consolidação da área.
\end{abstract}

Palavras-chave: Educação de Jovens e Adultos. Estado do conhecimento. Formação de Professores.

Abstract: The article presents the mapping of academic productions in the field of Youth and Adult Education (EJA) published in the periodicals Revista Tempos e Espaços em Educação and Revista Práxis Educacional. Using the State of the Art as a methodological path, forty-five articles were initially inventoried that discuss themes related to EJA throughout the period of existence of the two journals. Considering that the greatest recurrence of productions was concentrated on the descriptor teacher training to work in EJA, we applied a time frame between 2010-2020 to analyze in more detail the articles focused on this theme. The results of this survey indicate that the

\footnotetext{
${ }^{1}$ Universidade Estadual do Sudoeste da Bahia (UESB). Vitória da Conquista, Bahia, Brasil.

2 Universidade Federal de Alfenas (UNIFAL). Alfenas, Minhas Gerais, Brasil.

${ }^{3}$ Universidade Estadual do Sudoeste da Bahia (UESB). Vitória da Conquista, Bahia, Brasil.
} 
productions in the area of EJA are multidimensional, with greater emphasis on the area of teacher training, which remains a fundamental theme for consolidating the area.

Keywords: Youth and Adult Education. State of knowledge. Teacher training.

Resumen: El artículo presenta el mapa de producciones académicas en el campo de la Educación de Jóvenes y Adultos (EJA) publicado en las revistas Revista Tempos e Espaços em Educação y Revista Práxis Educacional. Utilizando el Estado del Arte como camino metodológico, inicialmente se inventariaron cuarenta y cinco artículos que tratan temas relacionados con EJA a lo largo del período de existencia de las dos revistas. Considerando que la mayor recurrencia de producciones se concentró en el descriptor formación docente para trabajar en EJA, se aplicó un marco temporal entre 2010-2020 para analizar con mayor detalle los artículos enfocados en esta temática. Los resultados de esta encuesta indican que las producciones en el área de EJA son multidimensionales, con mayor énfasis en el área de formación docente, que sigue siendo un tema fundamental para la consolidación del área.

Palabras clave: Educación de jóvenes y adultos. Estado del conocimiento. Formación de profesores.

\section{INTRODUÇÃO}

O crescimento exponencial das pesquisas nacionais sobre a Educação de Jovens e Adultos (EJA) no período recente reflete o avanço que esse campo da educação, seja pela sua maior institucionalização ou na superação dos desafios decorrentes dela, vem apresentando últimos anos. Nesse sentido, conhecer as produções acadêmicas voltadas para essa modalidade educativa nos permite dimensionar os principais estudos, experiências, contribuições e reflexões que subsidiam o debate sobre as pesquisas na EJA na atualidade.

Objetivamos apresentar neste artigo o estado do conhecimento das pesquisas em EJA publicadas nos periódicos vinculados aos Programas de Pós-graduação em Educação de duas universidades localizadas no nordeste brasileiro: a Universidade Federal de Sergipe (UFS) e a Universidade Estadual do Sudoeste da Bahia (UESB).

Vinculada ao Programa de Pós-Graduação em Educação da UFS, a revista Tempos e Espaços em Educação apresenta como foco e escopo, publicar em fluxo contínuo artigos originais, fomentando e facilitando o intercâmbio acadêmico da área de educação no âmbito nacional e internacional, priorizando estudos na área de história da educação, conhecimento e cultura, educação e comunicação, educação e diversidade e formação de professores.

A revista Práxis Educacional, periódico do Programa de Pós-Graduação em Educação da UESB, tem como objetivo fazer circular entre a comunidade acadêmica estudos voltados para a área da educação. A revista tem como princípio disponibilizar o conhecimento científico produzido, 
democratizando o acesso ao conhecimento e proporcionando a seus leitores maior profundidade no campo dos saberes educacionais.

A escolha dos periódicos em tela ocorreu pela grande representatividade que possuem na área das pesquisas cientificas em educação no Brasil, mais especificamente para região nordeste e Estados da Bahia e Sergipe, que juntos possuem doze programas de Pós-Graduação em Educação, seis acadêmicos e seis profissionais, encontrando nesses periódicos grande vazão dos resultados de suas pesquisas.

Destacamos também que as revistas Tempos e Espaços em Educação e Práxis Educacional, possuem elevada qualificação no extrato de avaliação de periódicos (QUALIS) da Coordenação de Aperfeiçoamento de Pessoal de Nível Superior (CAPES), o que situa a importância nacional e internacional dos dois periódicos.

O caminho metodológico adotado para esta análise, caracterizado como estado do conhecimento ${ }^{4}$, permite que os pesquisadores tenham maior familiarização sobre o que se tem produzido em relação à temática analisada, possibilitando melhor entendimento no que diz respeito ao conhecimento produzido, bem como as lacunas existentes na área.

De acordo com HADDAD (2000), os estudos do tipo estado do conhecimento permitem ao pesquisador, sistematizar um determinado campo de conhecimento, além de "identificar temáticas e abordagens dominantes e emergentes, bem como campos inexplorados abertos à pesquisa futura" (p. 04).

Para mapear a quantidade de artigos publicados nos dois periódicos, realizamos inicialmente uma busca aplicando um recorte temporal entre os anos de 2010 e 2020, porém, ao fazer uma análise mais detalhada, optamos para este critério o mapeamento de todas as publicações disponíveis no portal de periódicos de ambas as revistas.

Embora a revista Tempos e Espaços em Educação organize os trabalhos publicados por período e área temática, ao ser realizada a mesma análise na revista Práxis Educacional, observamos que esta não possui a mesma característica organizacional, o que nos levou optar pela utilização de descritores, de modo que fossem observadas as mesmas características temáticas em ambas as revistas. Assim, foram elencados os seguintes descritores: Evasão Escolar; Interdisciplinaridade; Formação de Professores; Políticas Públicas e Práticas Educativas.

\footnotetext{
4 As pesquisas denominadas, em geral, de "Estado da Arte" ou "Estado do Conhecimento", são caracterizadas por se tratar "de um instrumento que busca a compreensão do conhecimento sobre determinado tema, em um período de tempo específico e consequentemente, sua sistematização e análise" (TEIXEIRA, 2006, p. 60).
} 
Diante da quantidade de trabalhos encontrados e considerando as limitações que se impõem em relação à extensão deste estudo, tomamos como referência para análise qualitativa os textos publicados entre 2010 a 2020 a partir do descritor formação de professores, por ter sido a temática com maior recorrência nas produções ${ }^{5}$.

\section{DA EJA EM CAMPO AO CAMPO DA EJA: NOTAS SOBRE A MULTIDIMENSIONALIDADE DESTA ÁREA DO CONHECIMENTO}

Frente à tarefa de elaborar um Estado do Conhecimento visando conhecer as principais tendências dos estudos referidos à Educação de Jovens e Adultos - EJA - em um dado recorte temporal e base bibliográfica específica, uma primeira questão se impõe: qual é, afinal, o campo da EJA? Embora possa parecer, ao leitor já acostumado a transitar pelas produções acadêmicocientíficas cada vez mais numerosas da área, uma questão de somenos importância, a busca por compreender qual é o campo teórico que se estrutura a partir e em torno da modalidade consiste em tarefa tão necessária quanto complexa, sobretudo quando se considera a extensão e abrangência de seus limites.

Sabe-se e denuncia-se, de longa data, a marginalidade com que a Educação de Jovens e Adultos - definida como modalidade voltada ao atendimento educacional às pessoas que não lograram concluir o nível básico da educação formal na chamada idade certa - se inscreve no campo das políticas educacionais de modo geral; do que resulta entre outros, a manutenção de elevados e vergonhosos índices de subescolarização na sociedade brasileira. Isso, por si só conforma um vasto horizonte de "perturbações pessoais" passíveis de serem convertidas em "questão pública da estrutura social" e, portanto, pertinentes para o desenvolvimento de estudos científicos (MILLS, 1969).

De igual modo e em sentido contrário, sabe-se e assiste-se historicamente ao vigoroso trabalho realizado por segmentos e sujeitos comprometidos com a emancipação dos cidadãos brasileiros que têm na negativa do direito à educação um dos mais poderosos mecanismos de perpetuação das condições que mantêm viva a desigualdade social, na criação de condições para tornar realidade o princípio legal da educação como direito de todas as pessoas, independentemente da idade. As ações empreendidas nesse sentido, assim como os processos nos 
quais se realizam e os resultados delas decorrentes constituem outro importante conjunto de questões passíveis de investigação.

E é em meio a esses dois extremos - negação do direito à educação e luta pela efetivação deste mesmo direito - que a EJA se afirma e ganha vida no campo da prática educativa; prática essa que sendo informada por bases teóricas e metodológicas consistentes, advindas de diversas áreas do conhecimento, se consubstancia no caráter praxiológico da modalidade. Nesse movimento, temse, por um lado, a diversificação das formas de incidência da EJA no campo educativo e, por outro lado, o delineamento de um campo de estudos dinâmico que, tal como caleidoscópio, revela diferentes nuances na medida em que, ao alimentar a prática é por ela informado, sendo reconfigurado pelo que nela se produz em termos de saberes e conhecimentos, num remodelar permanente.

Tal entendimento aponta incialmente, para o reconhecimento de que, no referente à forma como a modalidade se materializa no campo educativo, mais adequado seria falar-se em educações de jovens e adultos, tendo na flexão gramatical numérica plural o indicativo do quão variadas são as formas pelas quais o atendimento educacional a pessoas subescolarizadas se faz no Brasil. Dentre os muitos aspectos que contribuem para essa variação da modalidade, destacamos a historicidade, os sujeitos e os processos educativos que nela se desenvolvem.

No primeiro caso, sobressai a constatação de que, como prática social, a educação de jovens e adultos acompanha a dinâmica sócio-histórica absorvendo - nunca sem traduções - as orientações e determinações de cada contexto político, econômico e cultural. Assim, em paralelo às diferentes concepções construídas em torno dessa modalidade, a oferta de oportunidades educacionais ao público elegível para a EJA também sofreu variações ao longo do tempo. Como resultado tem-se que, em perspectiva histórica, a incidência da modalidade no campo educativo, assim como a própria modalidade, apresentam ao campo teórico inquietações e objetivos novos e/ou renovados, cujo estudo tem o potencial de lançar luz sobre os modos de atendimento (ou não) às populações subescolarizadas no Brasil.

A título de exemplo pode-se considerar o processo de transformação que a definição da modalidade experimentou ao longo da história sistematizado, em linhas gerais no excerto abaixo:

A expressão de uso predominante até a década de cinquenta foi "Educação de Adultos", cuja ideia remetia ao destinatário da modalidade, evidenciando que, nessa época, a educação de adultos era pensada para o adulto, sobretudo o analfabeto. No final dos anos cinquenta, "Educação de Adultos" passa a ser designada como "Educação Popular", ressaltando a dimensão política contida nas propostas desenvolvidas por determinados segmentos sociais, sob inspiração dos 
estudos de Paulo Freire. Nos anos oitenta vê-se a emergência da expressão "Educação de Adultos Trabalhadores" pondo-se em relevo uma dimensão classista até então não considerada; por fim, a partir dos anos noventa, a expressão "Educação de Jovens e Adultos" passa a figurar com mais frequência, indicando a necessidade de se incorporar o segmento jovem nos programas anteriormente destinados aos adultos, pois a precocidade do ingresso no mercado de trabalho e o recorrente fracasso escolar entre os jovens acabam por excluí-los do ensino regular, transformando-os em demandatários potenciais de EJA. (SANTOS, 2001, p. 11)

O segundo aspecto que aqui se destaca como vetor da variação das formas de incidência da EJA no campo educativo e, por extensão, da delimitação do campo dos estudos a ela referido, insinuada no excerto acima, são os sujeitos aos quais ela se destina. Se, por princípio, o fato de se voltar ao atendimento educacional de pessoas que não ingressaram na escola regular ou dela foram excluídas precocemente consiste no elemento distintivo, por excelência, da modalidade, os segmentos sociais legalmente reconhecidos como titulares deste direito também registram variação ao longo do tempo, havendo uma relação estreita entre o modo de concebê-la e a definição do público a ela elegível.

Assim, tem-se que, se nos idos dos anos de 1950 a "educação de adultos" consistia no modo de atendimento escolar às pessoas analfabetas, chega-se aos anos de 1990 à expressão "Educação de Jovens e Adultos"; a qual tem se mostrado limitada em face da necessidade de dar visibilidade aos adolescentes - jovens cada vez mais novos - e aos idosos - adultos cada vez mais maduros que têm registrado participação crescente nas ações da modalidade. Consistindo em um dos mais emblemáticos aspectos que nuançam o campo das práticas educativas e o campo teórico da modalidade, a variação etária de seu público, em perspectiva histórica, e a heterogeneidade sob a qual ele se compõe na atualidade pode ser entendida como uma potente mola propulsora da dinamicidade aqui discutida.

Como terceiro e último elemento de grande importância na conformação do caráter dinâmico do campo das práticas educativas e do campo teórico da EJA destacam-se os múltiplos processos educativos que a modalidade abriga, cuja variação acompanha tanto a dimensão da contextualidade quanto a dimensão da heterogeneidade do público. Da inter-relação entre esses dois aspectos, somada à dimensão continental do Brasil e à diversidade sob a qual a sociedade brasileira se organiza e responde aos desafios e necessidades que, mesmo sendo universais, impactam diferentemente a cada localidade, resulta uma profusão de ações e processos educativos variáveis em termos de forma, conteúdo, objetivos, público participante etc. De caráter formal e, também, não formal essas ações são empreendidas tanto por órgãos governamentais, tendo na 
maioria dos casos, a instituição escolar como lócus, quanto por organizações da sociedade civil de natureza e orientação diversas, que têm na dispersão dos lugares sociais o campo de realização.

Conforme tem-se refletido até aqui, a essa amplitude do campo de práticas educativas corresponde a ampliação, em igual medida, do campo teórico referido à modalidade que informa essas práticas e é por elas informado em uma retroalimentação dialética que confere o caráter multidimensional da Educação de Jovens e Adultos.

Longe de ser sugestiva de uma possível fragmentação desse campo teórico - considerandose os cânones da ortodoxia científica - essa multidimensionalidade revela sua riqueza uma vez que, diferentemente de se deixar aprisionar na focalização de temas e objetos dados aprioristicamente, ele é continuamente impelido pelo ímpeto dos pesquisadores, no sentido do acompanhamento da dinâmica da modalidade que, por sua vez, se move ao ritmo da dinâmica social, imprimindo, nela, a marca da resistência do princípio da garantia e efetivação do direito à educação, para todas as pessoas, independentemente da idade.

Do entendimento de que a totalidade EJA, definida por sua pluralidade teórico-prática, se assenta no reconhecimento da força da negação do direito à educação a quem a ela não teve acesso tal como preconizado na legislação brasileira e na contraposição que a luta social pela reversão dessa negativa enseja emerge a pertinência do estado da arte que aqui se apresenta, dado ser possível, por essa via, (re) conhecer parte do que a modalidade abriga - como prática - e o que nela se produz - como conhecimento - informando e inspirando novos fazeres e pensares que venham a se somar a esse grande movimento que caracteriza a área.

\section{ESTADO DO CONHECIMENTO DAS PESQUISAS EM EJA NAS REVISTAS TEMPOS E ESPAÇOS EM EDUCAÇÃO E PRÁXIS EDUCACIONAL}

Para efeito de organização deste texto, apresentamos inicialmente os dados quantitativos da pesquisa, em seguida a discussão com as informações levantadas sobre a EJA nos textos selecionados para análise. 
QUADRO 01 - REVISTA TEMPOS E ESPAÇO EM EDUCAÇÃO - UFS

\begin{tabular}{|c|c|c|c|c|c|c|}
\hline \multicolumn{7}{|c|}{ ÁREAS TEMÁTICAS } \\
\hline ANO & $\begin{array}{l}\text { Evasão } \\
\text { Escolar }\end{array}$ & Interdisciplinaridade & $\begin{array}{c}\text { Formação de } \\
\text { Professores }\end{array}$ & $\begin{array}{l}\text { Políticas } \\
\text { Públicas }\end{array}$ & $\begin{array}{c}\text { Práticas } \\
\text { Educativas }\end{array}$ & TOTAL \\
\hline 2008 & & & & & & 00 \\
\hline 2009 & & & & & & 00 \\
\hline 2010 & 01 & & & & & 01 \\
\hline 2011 & & & & & & 00 \\
\hline 2012 & & & 01 & & & 01 \\
\hline 2013 & & 01 & & 01 & & 02 \\
\hline 2014 & & & & & & 00 \\
\hline 2015 & & & & & & 00 \\
\hline 2016 & & & & & & 00 \\
\hline 2017 & & & & & & 00 \\
\hline 2018 & & & & 02 & & 02 \\
\hline 2019 & & & & & 01 & 01 \\
\hline 2020 & & 01 & & & & 01 \\
\hline TOTAL & 01 & 02 & 01 & 03 & 01 & 08 \\
\hline
\end{tabular}

Fonte: Dados coletados nas pesquisas realizadas no portal de periódicos da revista Tempos e Espaços em Educação Jul. 2020. Elaboração dos autores.

QUADRO 02 - REVISTA PRÁXIS EDUCACIONAL - UESB

\begin{tabular}{|c|c|c|c|c|c|c|}
\hline \multicolumn{7}{|c|}{ ÁREAS TEMÁTICAS } \\
\hline ANO & $\begin{array}{l}\text { Evasão } \\
\text { Escolar }\end{array}$ & Interdisciplinaridade & $\begin{array}{c}\text { Formação de } \\
\text { Professores }\end{array}$ & $\begin{array}{c}\text { Políticas públicas } \\
\text { para EJA }\end{array}$ & Práticas Educativas & TOTAL \\
\hline 2005 & & & & & & 00 \\
\hline 2006 & & 01 & 01 & & & 02 \\
\hline 2007 & & & & & 01 & 01 \\
\hline 2008 & & & & & 02 & 02 \\
\hline 2009 & & 01 & 05 & 02 & 03 & 11 \\
\hline 2010 & & & 01 & & & 01 \\
\hline 2011 & & & & & 01 & 01 \\
\hline 2012 & & & & & & 00 \\
\hline 2013 & & & & 01 & & 01 \\
\hline 2014 & & & & & & 00 \\
\hline 2015 & & & & & & 00 \\
\hline 2016 & & 01 & 01 & & & 02 \\
\hline 2017 & & & & 01 & & 01 \\
\hline 2018 & & & 03 & 03 & 02 & 08 \\
\hline 2019 & & 03 & 01 & 01 & & 05 \\
\hline 2020 & & & 01 & 01 & & 02 \\
\hline
\end{tabular}




\begin{tabular}{|l|l|l|l|l|l|l|}
\hline TOTAL & 00 & 06 & 13 & 09 & 09 & 37 \\
\hline
\end{tabular}

Fonte: Dados coletados nas pesquisas realizadas no portal de periódicos da revista Práxis Educacional. Jul. 2020. Elaboração dos autores.

Uma vez selecionadas e contabilizadas as produções com base nos descritores já mencionados, passamos à fase seguinte, que foi analisar os resumos e referenciais bibliográficos de toda a seleção, pois, tendo como propósito saber como andam as produções e quais os principais assuntos sobre a modalidade EJA estão presentes no campo científico das pesquisas em educação, ficou definido que os textos selecionados não tinha a necessidade de serem lidos na íntegra.

A seguir, apresentamos as produções selecionadas nas revistas Tempos e Espaços em Educação (quadro 03) e Práxis Educacional (quadro 04).

\section{QUADRO 03: SELEÇÃO DAS PRODUÇÕES ANALISADAS NA REVISTA TEMPOS E ESPAÇOS EM EDUCAÇÃO - UFS}

\begin{tabular}{|c|c|c|c|c|}
\hline Ano & Produção & Autor & $\begin{array}{l}\text { Titulação autor } \\
\text { principal }^{6}\end{array}$ & Instituição \\
\hline 2010 & $\begin{array}{c}\text { Os jovens e os adultos que fogem da } \\
\text { escola: a escola que expulsa os jovens } \\
\text { e os adultos: reflexões sobre o } \\
\text { abandono na EJA }\end{array}$ & $\begin{array}{l}\text { Neto, J. C. da S., \& } \\
\text { Andrade, M. C. N. } \\
\text { (1). }\end{array}$ & Doutorando & UNIT-SE \\
\hline 2012 & $\begin{array}{c}\text { A pedagogia intercultural na } \\
\text { formação docente para educação de } \\
\text { jovens e adultos - compromisso } \\
\text { social das IES no Brasil }\end{array}$ & $\begin{array}{l}\text { Almeida, M. J. de } \\
\text { M. (1). }\end{array}$ & $\begin{array}{l}\text { Doutor em } \\
\text { Ciências da } \\
\text { Educação }\end{array}$ & $\begin{array}{l}\text { Universidad } \\
\text { Autónoma de } \\
\text { Asunción } \\
\end{array}$ \\
\hline 2013 & $\begin{array}{c}\text { Saberes pedagógicos na educação de } \\
\text { jovens e adultos }\end{array}$ & $\begin{array}{l}\text { Silveira, M. M., de } \\
\text { Santana, J. S., \& } \\
\text { Costa, E. F. X. (1). }\end{array}$ & $\begin{array}{l}\text { Mestra em } \\
\text { Geografia }\end{array}$ & $\begin{array}{l}\text { Universidade } \\
\text { Federal de } \\
\text { Sergipe } \\
\end{array}$ \\
\hline 2013 & $\begin{array}{c}\text { A dimensão ambiental na educação } \\
\text { de jovens e adultos: possibilidades e } \\
\text { desafios }\end{array}$ & $\begin{array}{l}\text { Rezende, V. A. } \\
\text { (1). }\end{array}$ & $\begin{array}{l}\text { Mestra em } \\
\text { Educação }\end{array}$ & $\begin{array}{l}\text { Universidade } \\
\text { Federal de } \\
\text { Sergipe }\end{array}$ \\
\hline 2018 & $\begin{array}{l}\text { A educação de jovens e adultos no } \\
\text { sistema prisional brasileiro: o que } \\
\text { dizem os planos estaduais de } \\
\text { educação em prisões? }\end{array}$ & Pereira, A. (2018). & $\begin{array}{l}\text { Doutor em } \\
\text { Educação }\end{array}$ & $\begin{array}{l}\text { Universidade } \\
\text { Federal da } \\
\text { Bahia }\end{array}$ \\
\hline 2019 & $\begin{array}{l}\text { Reflexões sobre formação de } \\
\text { formadores para o proeja: o caso do } \\
\text { Instituto Federal de Santa Catarina. }\end{array}$ & $\begin{array}{l}\text { Ribeiro, I., Laffin, } \\
\text { M. H. L. F., \& } \\
\text { Aguiar, P. A. de. } \\
\text { (2019). }\end{array}$ & $\begin{array}{l}\text { Doutoranda em } \\
\text { Educação }\end{array}$ & $\begin{array}{l}\text { Universidade } \\
\text { Federal de } \\
\text { Santa Catarina }\end{array}$ \\
\hline 2019 & $\begin{array}{c}\text { Prática pedagógica docente na } \\
\text { educação de jovens e adultos } \\
\text { privados de liberdade pertencentes a } \\
\text { uma unidade prisional }\end{array}$ & $\begin{array}{l}\text { Miranda, M. L. F., } \\
\text { Vasconcelos, C. F. } \\
\text { C., \& Justi, J. } \\
\text { (2019). }\end{array}$ & $\begin{array}{l}\text { Pós-Graduanda } \\
\text { em Gestão, } \\
\text { Supervisão e } \\
\text { Orientação } \\
\text { Educacional }\end{array}$ & $\begin{array}{c}\text { Centro } \\
\text { Universitário } \\
\text { FAMETRO - AM }\end{array}$ \\
\hline
\end{tabular}

6 A titulação e Instituição dos autores estão de acordo com a data de publicação da revista, podendo um mesmo autor ter diferentes titulações e instituições na mesma tabela. 


\begin{tabular}{|c|c|c|c|c|}
\hline 2020 & $\begin{array}{c}\text { Desafíos del siglo XXI para la } \\
\text { educación popular: nuevos } \\
\text { fundamentos para nuevas prácticas }\end{array}$ & Leite, I. (2020). & $\begin{array}{c}\text { Pós-doctorado en } \\
\text { Sociología }\end{array}$ & $\begin{array}{c}\text { Universidad de } \\
\text { la República } \\
\text { (Uruguay) }\end{array}$ \\
\hline
\end{tabular}

Fonte: Dados coletados nas pesquisas realizadas no portal de periódicos da Revista Tempos e Espaços em Educação Jul. 2020. Elaboração dos autores.

\section{QUADRO 04: SELEÇÃO DAS PRODUÇÕES ANALISADAS NA REVISTA PRÁXIS EDUCACIONAL - UESB}

\begin{tabular}{|c|c|c|c|c|}
\hline Ano & Produção & Autor & Titulação & Instituição \\
\hline 2006 & $\begin{array}{l}\text { Investigação-ação na formação de } \\
\text { profissionais pesquisadores(as): uma } \\
\text { experiência no ciclo de } \\
\text { aprendizagem e na educação de } \\
\text { pessoas jovens e adultas }\end{array}$ & $\begin{array}{l}\text { Pinto De Amorim } \\
\text { Leite, Maria Iza; } \\
\text { Reis dos Santos, } \\
\text { José Jackson. }\end{array}$ & $\begin{array}{l}\text { Doutora em } \\
\text { Educação }\end{array}$ & $\begin{array}{l}\text { Universidade } \\
\text { Federal da Bahia }\end{array}$ \\
\hline 2006 & $\begin{array}{c}\text { Educação do campo: alfabetização e } \\
\text { escolarização de pessoas jovens e } \\
\text { adultas assentadas no sudoeste da } \\
\text { Bahia } \\
\end{array}$ & $\begin{array}{l}\text { Marques Jardim, } \\
\text { Silvia Regina; } \\
\text { Costa, Sidiney } \\
\text { Alves. }\end{array}$ & $\begin{array}{l}\text { Mestre em } \\
\text { Educação }\end{array}$ & $\begin{array}{l}\text { Universidade } \\
\text { Estadual do } \\
\text { Sudoeste da } \\
\text { Bahia }\end{array}$ \\
\hline 2007 & $\begin{array}{c}\text { Práticas pedagógicas crítico } \\
\text { emancipatórias: em educação de } \\
\text { pessoas jovens,adultas e idosas }\end{array}$ & $\begin{array}{l}\text { Reis dos Santos, } \\
\text { José Jackson. }\end{array}$ & $\begin{array}{l}\text { Mestre em } \\
\text { Educação }\end{array}$ & $\begin{array}{l}\text { Universidade de } \\
\text { Passo Fundo (RS) }\end{array}$ \\
\hline 2008 & $\begin{array}{l}\text { Concepções e práticas de escrita } \\
\text { numa classe de alfabetização de } \\
\text { jovens e adultos }\end{array}$ & $\begin{array}{l}\text { Santos Pereira, } \\
\text { Josilene } \\
\text { Domingues. }\end{array}$ & Mestra em Letras & $\begin{array}{l}\text { Universidade } \\
\text { Federal da Bahia }\end{array}$ \\
\hline 2008 & $\begin{array}{l}\text { O currículo na educação de jovens e } \\
\text { adultos: entre o formal e o cotidiano } \\
\text { numa escola municipal em belo } \\
\text { horizonte }\end{array}$ & $\begin{array}{l}\text { Eugênio, } \\
\text { Benedito } \\
\text { Gonçalves. }\end{array}$ & $\begin{array}{l}\text { Doutorando em } \\
\text { Educação }\end{array}$ & $\begin{array}{l}\text { Universidade } \\
\text { Estadual de } \\
\text { Campinas }\end{array}$ \\
\hline 2009 & $\begin{array}{l}\text { Educação de jovens e adultos: uma } \\
\text { história de complexidade e tensões }\end{array}$ & $\begin{array}{l}\text { Sampaio, Marisa } \\
\text { Narcizo }\end{array}$ & $\begin{array}{l}\text { Doutora em } \\
\text { Educação. }\end{array}$ & $\begin{array}{l}\text { Universidade } \\
\text { Federal do Rio } \\
\text { Grande do Norte. }\end{array}$ \\
\hline 2009 & $\begin{array}{c}\text { Formação de educadores de jovens } \\
\text { e adultos: realidade, desafios e } \\
\text { perspectivas atuais }\end{array}$ & $\begin{array}{l}\text { de Melo Moura, } \\
\text { Tania Maria. }\end{array}$ & $\begin{array}{l}\text { Estágio pós- } \\
\text { doutoral }\end{array}$ & $\begin{array}{l}\text { Universidade do } \\
\text { Porto - Portugal }\end{array}$ \\
\hline 2009 & $\begin{array}{l}\text { O desafio das novas oportunidades } \\
\text { educativas em Portugal }\end{array}$ & $\begin{array}{l}\text { de Brito Simões } \\
\text { Dos Santos, } \\
\text { Maria Rosa. }\end{array}$ & $\begin{array}{l}\text { Mestranda em } \\
\text { Ciências da } \\
\text { Educação }\end{array}$ & $\begin{array}{l}\text { Universidade de } \\
\text { Lisboa }\end{array}$ \\
\hline 2009 & $\begin{array}{l}\text { Contributos para o estudo do } \\
\text { desenvolvimento do adulto: } \\
\text { reflexões em torno da } \\
\text { generatividade }\end{array}$ & $\begin{array}{l}\text { Rebelo, Piedade } \\
\text { Vaz; Borges, } \\
\text { Graciete Franco. }\end{array}$ & $\begin{array}{l}\text { Doutora em } \\
\text { Psicologia } \\
\text { Educacional }\end{array}$ & $\begin{array}{l}\text { Faculdade de } \\
\text { Ciências e } \\
\text { Tecnologia da } \\
\text { Universidade de } \\
\text { Coimbra } \\
\end{array}$ \\
\hline 2009 & $\begin{array}{c}\text { O não-lugar da pessoa idosa na } \\
\text { educação }\end{array}$ & $\begin{array}{l}\text { Paula, Rouseane } \\
\text { da Silva. }\end{array}$ & $\begin{array}{l}\text { Doutoranda em } \\
\text { Educação }\end{array}$ & $\begin{array}{c}\text { Universidade } \\
\text { Federal do Rio } \\
\text { Grande do Norte }\end{array}$ \\
\hline 2009 & $\begin{array}{l}\text { A trajetória da EJA no estado da } \\
\text { Bahia: da suplência à aceleração }\end{array}$ & $\begin{array}{c}\text { Furtado Sales, } \\
\text { Sheila Cristina; } \\
\text { Cotrim Costa, } \\
\text { Gicélia } \\
\text { Aparecida; } \\
\text { Oliveira, } \\
\text { Jurenilda Prado. }\end{array}$ & $\begin{array}{l}\text { Doutora em } \\
\text { Educação }\end{array}$ & $\begin{array}{l}\text { Universidade } \\
\text { Federal de São } \\
\text { Carlos }\end{array}$ \\
\hline
\end{tabular}




\begin{tabular}{|c|c|c|c|c|}
\hline 2009 & $\begin{array}{l}\text { As séries iniciais da educação de } \\
\text { jovens e adultos em nível municipal } \\
\text { e as políticas públicas } \\
\text { implementadas - em busca de novos } \\
\text { significados }\end{array}$ & $\begin{array}{l}\text { Venâncio, João } \\
\text { Carlos; } \\
\text { Garboggini di } \\
\text { Giorgi, Cristiano } \\
\text { Amaral. }\end{array}$ & $\begin{array}{l}\text { Mestrando em } \\
\text { educação }\end{array}$ & $\begin{array}{l}\text { Faculdade de } \\
\text { Tecnologia e } \\
\text { Ciências - UNESP }\end{array}$ \\
\hline 2009 & $\begin{array}{l}\text { O percurso formativo dos } \\
\text { professores/pesquisadores da EJA } \\
\text { na contemporaneidade }\end{array}$ & $\begin{array}{l}\text { Da Silva De Faria, } \\
\text { Edite Maria. }\end{array}$ & $\begin{array}{l}\text { Mestranda em } \\
\text { Educação e } \\
\text { Contemporaneidade }\end{array}$ & $\begin{array}{l}\text { Universidade do } \\
\text { Estado da Bahia }\end{array}$ \\
\hline 2009 & $\begin{array}{l}\text { (In) congruências na orientação } \\
\text { metodológica dos professores: } \\
\text { análise nas dimensões da prática } \\
\text { educativa (resultados comparativos } \\
\text { numa amostra de professores de } \\
\text { português, matemática e inglês). }\end{array}$ & $\begin{array}{l}\text { Couceiro figueira, } \\
\text { Ana Paula. }\end{array}$ & $\begin{array}{l}\text { Doutora em } \\
\text { Psicologia }\end{array}$ & $\begin{array}{l}\text { Universidade de } \\
\text { Coimbra }\end{array}$ \\
\hline 2009 & $\begin{array}{l}\text { A educação matemática de jovens e } \\
\text { adultos no ensino superior de } \\
\text { administração: relato de } \\
\text { experiências na Universidade } \\
\text { Federal do Tocantins. }\end{array}$ & $\begin{array}{l}\text { Iwamoto, Helga } \\
\text { Midori. }\end{array}$ & $\begin{array}{c}\text { Mestre em } \\
\text { Administração }\end{array}$ & $\begin{array}{l}\text { Universidade } \\
\text { Federal do } \\
\text { Espírito Santo }\end{array}$ \\
\hline 2009 & $\begin{array}{c}\text { A experiência de alfabetização de } \\
\text { jovens e adultos do Programa Re- } \\
\text { aprender no conjunto penal de } \\
\text { Jequié-Bahia }\end{array}$ & $\begin{array}{l}\text { De Mello, Fábio } \\
\text { Mansano; } \\
\text { Moreira, Josinélia } \\
\text { dos Santos. } \\
\end{array}$ & $\begin{array}{l}\text { Mestrado em } \\
\text { Ciências Sociais }\end{array}$ & $\begin{array}{l}\text { Universidade } \\
\text { Estadual de } \\
\text { Londrina }\end{array}$ \\
\hline 2010 & $\begin{array}{c}\text { Especificidades dos saberes para a } \\
\text { docência na educação de pessoas } \\
\text { jovens e adultas }\end{array}$ & $\begin{array}{l}\text { Reis dos Santos, } \\
\text { José Jackson. }\end{array}$ & $\begin{array}{l}\text { Doutor em } \\
\text { Educação }\end{array}$ & $\begin{array}{l}\text { Universidade } \\
\text { Federal do Rio } \\
\text { Grande do } \\
\text { Norte }\end{array}$ \\
\hline 2011 & $\begin{array}{l}\text { Saberes necessários para a docência } \\
\text { na educação de jovens e adultos. }\end{array}$ & $\begin{array}{l}\text { Reis dos Santos, } \\
\text { José Jackson. }\end{array}$ & $\begin{array}{l}\text { Doutor em } \\
\text { Educação }\end{array}$ & $\begin{array}{l}\text { Universidade } \\
\text { Federal do Rio } \\
\text { Grande do } \\
\text { Norte }\end{array}$ \\
\hline 2013 & $\begin{array}{l}\text { Educação e formação de adultos: } \\
\text { políticas, práticas e investigação }\end{array}$ & $\begin{array}{l}\text { Sobral, Maria } \\
\text { Neide. }\end{array}$ & $\begin{array}{l}\text { Doutora em } \\
\text { Educação, }\end{array}$ & $\begin{array}{l}\text { Universidade } \\
\text { Federal do Rio } \\
\text { Grande do Norte }\end{array}$ \\
\hline 2016 & $\begin{array}{l}\text { Alfabetização de adultos: uma } \\
\text { ferramenta para a sustentabilidade }\end{array}$ & $\begin{array}{l}\text { Alves, José Luiz; } \\
\text { Câncio, Daniela } \\
\text { de Oliveira. }\end{array}$ & $\begin{array}{l}\text { Doutor } \\
\text { em Geografia }\end{array}$ & $\begin{array}{l}\text { Universidade } \\
\text { Federal de } \\
\text { Pernambuco }\end{array}$ \\
\hline 2016 & $\begin{array}{c}\text { Formação continuada com } \\
\text { professoras alfabetizadoras de } \\
\text { jovens e adultos: uma experiência } \\
\text { para ser compartilhada } \\
\end{array}$ & $\begin{array}{l}\text { Legemann } \\
\text { Oliveira, Marli } \\
\text { Pardo; Schwartz, } \\
\text { Suzana. } \\
\end{array}$ & $\begin{array}{l}\text { Mestra em } \\
\text { Educação }\end{array}$ & $\begin{array}{l}\text { UNIPAMPA - } \\
\text { Jaguarão/RS }\end{array}$ \\
\hline 2017 & $\begin{array}{c}\text { A inclusão de alunos com } \\
\text { necessidades educacionais especiais } \\
\text { na educação de jovens e adultos: } \\
\text { algumas discussões }\end{array}$ & $\begin{array}{l}\text { Silva Miron, } \\
\text { Keren Talita; } \\
\text { Alves de Oliveira } \\
\text { Reis, Sônia } \\
\text { Maria. } \\
\end{array}$ & $\begin{array}{l}\text { Mestranda em } \\
\text { Educação }\end{array}$ & $\begin{array}{l}\text { Instituto Federal } \\
\text { Catarinense }\end{array}$ \\
\hline 2018 & Especialização proeja CEFET/IFRN & $\begin{array}{l}\text { De Morais, João } \\
\text { Kaio Cavalcante; } \\
\text { Henrique, Ana } \\
\text { Lúcia Sarmento. }\end{array}$ & $\begin{array}{l}\text { Mestre em } \\
\text { Educação }\end{array}$ & $\begin{array}{l}\text { Universidade } \\
\text { Federal do Rio } \\
\text { Grande do } \\
\text { Norte }\end{array}$ \\
\hline 2018 & $\begin{array}{l}\text { Entre o ser e o ter: dilemas e } \\
\text { sentidos da educação de adultos }\end{array}$ & $\begin{array}{l}\text { Silva, Daniela } \\
\text { Vilaverde e. }\end{array}$ & $\begin{array}{l}\text { Mestra em } \\
\text { Organizações } \\
\text { Educativas e } \\
\text { Administração } \\
\text { Educacional }\end{array}$ & $\begin{array}{l}\text { University of } \\
\text { Minho }\end{array}$ \\
\hline
\end{tabular}




\begin{tabular}{|c|c|c|c|c|}
\hline 2018 & $\begin{array}{l}\text { Formação docente, práxis } \\
\text { pedagógica no contexto midiático da } \\
\text { EJA }\end{array}$ & $\begin{array}{l}\text { Oliveira, Maria } \\
\text { Olivia de Matos; } \\
\text { Dantas, Tania } \\
\text { Regina. }\end{array}$ & Ph.D & $\begin{array}{l}\text { Universidade do } \\
\text { Estado do Rio de } \\
\text { Janeiro }\end{array}$ \\
\hline 2018 & $\begin{array}{l}\text { Por la defensa del derecho a la } \\
\text { educación de los jóvenes y adultos } \\
\text { en américa latina y el caribe }\end{array}$ & $\begin{array}{l}\text { Rossel, Nélida } \\
\text { Céspedes. }\end{array}$ & $\begin{array}{c}\text { Educadora peruana. } \\
\text { Secretaria general } \\
\text { del Consejo de } \\
\text { Educación Popular } \\
\text { de América Latina y } \\
\text { el Caribe }\end{array}$ & $\begin{array}{l}\text { Consejo de } \\
\text { Educación } \\
\text { Popular de } \\
\text { América Latina y } \\
\text { el Caribe-Peru }\end{array}$ \\
\hline 2018 & $\begin{array}{l}\text { Juventude negra e educação de } \\
\text { jovens e adultos (EJA): reflexões na } \\
\text { perspectiva da teoria da resiliência }\end{array}$ & $\begin{array}{l}\text { Valentim, Silvani } \\
\text { Dos Santos; Assis, } \\
\text { Neusa Pereira } \\
\text { De. }\end{array}$ & $\begin{array}{l}\text { Ph.D em Educação - } \\
\text { Gestão e Políticas } \\
\text { Educacionais }\end{array}$ & $\begin{array}{c}\text { Temple } \\
\text { University, USA }\end{array}$ \\
\hline 2018 & $\begin{array}{c}\text { Educação de jovens e adultos no } \\
\text { sistema prisional: reinserção social } \\
\text { de mulheres }\end{array}$ & $\begin{array}{l}\text { Oliveira, } \\
\text { Suzianne Silva } \\
\text { de; Oliveira, } \\
\text { Ivanilde } \\
\text { Apoluceno de. } \\
\end{array}$ & $\begin{array}{l}\text { Mestra em } \\
\text { Educação }\end{array}$ & $\begin{array}{l}\text { Universidade do } \\
\text { Estado do Pará }\end{array}$ \\
\hline 2018 & $\begin{array}{l}\text { Prevenção ao uso de drogas na } \\
\text { educação de jovens e adultos }\end{array}$ & $\begin{array}{l}\text { Moura, Maria Da } \\
\text { Glória Carvalho; } \\
\text { Melo, Belisa } \\
\text { Maria da Silva. }\end{array}$ & $\begin{array}{l}\text { Doutorado em } \\
\text { Educação }\end{array}$ & $\begin{array}{l}\text { Universidade } \\
\text { Federal do Rio } \\
\text { Grande do Norte }\end{array}$ \\
\hline 2018 & $\begin{array}{l}\text { O uso (crítico) das tecnologias } \\
\text { digitais da informação e da } \\
\text { comunicação na educação (não } \\
\text { compensatória) de jovens e adultos. }\end{array}$ & $\begin{array}{l}\text { Joaquim, Bruno } \\
\text { dos Santos; } \\
\text { Pesce, Lucila. }\end{array}$ & $\begin{array}{l}\text { Doutor em } \\
\text { Educação }\end{array}$ & $\begin{array}{l}\text { Universidade } \\
\text { Federal do } \\
\text { Estado de São } \\
\text { Paulo }\end{array}$ \\
\hline 2019 & $\begin{array}{l}\text { Os sujeitos da EJA e da educação } \\
\text { social: as pessoas em situação de } \\
\text { vulnerabilidade social }\end{array}$ & Pereira, Antonio. & $\begin{array}{l}\text { Doutor em } \\
\text { Educação }\end{array}$ & $\begin{array}{c}\text { Universidade } \\
\text { Federal da Bahia } \\
\text { (UFBA) }\end{array}$ \\
\hline 2019 & $\begin{array}{c}\text { As experiências dos licenciandos em } \\
\text { ciências biológicas com a educação } \\
\text { de jovens e adultos }\end{array}$ & $\begin{array}{l}\text { Costa Santos da } \\
\text { Paixão, Marília; } \\
\text { Bruno Araújo } \\
\text { Queiroz, } \\
\text { Marcelo; Andréa } \\
\text { Vianna } \\
\text { Prudêncio, } \\
\text { Christiana. }\end{array}$ & $\begin{array}{l}\text { Mestranda em } \\
\text { Educação }\end{array}$ & $\begin{array}{l}\text { Universidade } \\
\text { Estadual de } \\
\text { Santa Cruz }\end{array}$ \\
\hline 2019 & $\begin{array}{l}\text { Para pensar e movimentar a } \\
\text { formação docente na EJA: um } \\
\text { mapeamento das produções } \\
\text { acadêmicas entre o período 2015- } \\
2016\end{array}$ & $\begin{array}{l}\text { Mauricio, Suelen } \\
\text { Santos; Junior, } \\
\text { Luiz Martins; } \\
\text { Martins, Rosa } \\
\text { Elisabete Militz } \\
\text { Wypyczynski. } \\
\end{array}$ & $\begin{array}{l}\text { Doutorando em } \\
\text { Educação }\end{array}$ & $\begin{array}{l}\text { Universidade do } \\
\text { Estado de Santa } \\
\quad \text { Catarina }\end{array}$ \\
\hline 2019 & $\begin{array}{c}\text { Trilhas da história oral: memórias da } \\
\text { educação de jovens e adultos em } \\
\text { alagoas }\end{array}$ & $\begin{array}{c}\text { Freitas, } \\
\text { Marinaide Lima } \\
\text { de Queiroz; Da } \\
\text { Silva, Jailson } \\
\text { Costa } \\
\end{array}$ & $\begin{array}{l}\text { Ph.D } \\
\text { Em Formação } \\
\text { Docente }\end{array}$ & $\begin{array}{l}\text { Universidade do } \\
\text { Porto, Portugal. }\end{array}$ \\
\hline 2019 & $\begin{array}{l}\text { The aesthetical literacy in the } \\
\text { consolidation of reading and writing } \\
\text { of young and adult peasants }\end{array}$ & $\begin{array}{l}\text { Araújo, Gustavo } \\
\text { Cunha De; } \\
\text { Miguel, José } \\
\text { Carlos; Silva, } \\
\text { Edimila Matos } \\
\text { da. }\end{array}$ & $\begin{array}{l}\text { Doutor em } \\
\text { Educação }\end{array}$ & $\begin{array}{l}\text { Universidade } \\
\text { Federal do } \\
\text { Tocantins, }\end{array}$ \\
\hline
\end{tabular}




\begin{tabular}{|c|c|c|c|c|}
\hline 2020 & $\begin{array}{c}\text { Educação profissional de jovens em } \\
\text { privação de liberdade }\end{array}$ & $\begin{array}{c}\text { Barbosa, Sílvia } \\
\text { Danizete Pereira; } \\
\text { Quirino, Raquel. } \\
\mathbf{2 0 2 0}\end{array}$ & $\begin{array}{c}\text { Mestra em } \\
\text { Educação } \\
\text { Tecnológica }\end{array}$ & $\begin{array}{c}\text { Centro Federal } \\
\text { de Educação } \\
\text { Tecnológica de } \\
\text { Minas Gerais }\end{array}$ \\
& $\begin{array}{c}\text { Estado do conhecimento: a } \\
\text { dialogicidade entre a educação } \\
\text { inclusiva e a educação de jovens e } \\
\text { adultos. }\end{array}$ & $\begin{array}{c}\text { Miron, Kerén } \\
\text { Talita Silva; } \\
\text { Schardosim, } \\
\text { Chris Royes. }\end{array}$ & $\begin{array}{c}\text { Mestranda em } \\
\text { Educação }\end{array}$ & $\begin{array}{c}\text { Instituto Federal } \\
\text { Catarinense }\end{array}$ \\
\hline
\end{tabular}

Fonte: Dados coletados nas pesquisas realizadas no portal de periódicos da Revista Práxis Educacional. Jul. 2020. Elaboração dos autores.

\subsection{Situando o quantitativo de produções por área temática, vinculação institucional e região geográfica.}

A análise quantitativa aponta que na revista Tempos e Espaços em Educação as oito produções relacionadas à EJA publicadas entre os anos de 2008 a 2020 encontram-se bastante diluídas por descritor. É importante destacar que embora na descrição da revista, disponível em seu portal, exista a informação que suas publicações foram iniciadas no ano de 1999 (versão impressa), na versão eletrônica, objeto desta análise, foram selecionadas produções publicadas a partir de 2008.

Em relação à publicação por região, maior parte das produções publicadas pela revista se concentra na região nordeste, constando duas produções vinculadas à UFS, uma produção da UNIT (SE) e uma da UFBA. Encontramos ainda uma produção na região norte; oriunda da FAMETRO; uma produção na região sul, oriunda da UFSC e duas produções internacionais (Paraguai e Uruguai).

Na revista Práxis Educacional encontramos, entre os anos de 2006 e 2020, trinta e sete produções no campo da EJA. As publicações estão concentradas em sua maioria no descritor formação de professores, com treze produções, seguidos dos descritores políticas públicas e práticas educativas com nove produções cada um e interdisciplinar com uma produção. Não foram encontradas produções para o descritor evasão escolar.

Em relação à publicação por região, a maioria das pesquisas também se encontram concentradas em produções oriundas na região nordeste, constando sete produções vinculadas a UFRN, três produções na UFBA, uma produção na UESB, uma na UNEB, uma na UESC e uma na UFPE. A região norte conta com uma publicação, vinculada à UEPA. Da região centro-oeste, encontramos apenas uma produção, vinculada a UFTO.

Seguindo para a região sudeste, encontramos sete publicações. Da região sul, encontramos seis publicações e, por fim, foram localizadas oito publicações internacionais (Portugal, Peru e Estados Unidos). 
Embora maior parte das publicações seja oriunda de pesquisas desenvolvidas em instituições localizadas no nordeste do país, a distribuição geográfica das produções aponta para o interesse de pesquisadores de diversas regiões e instituições do Brasil e do exterior. Ademais, o quantitativo das publicações sinaliza para o já adscrito anteriormente, tanto do ponto de vista da multidimensionalidade das pesquisas nesse campo da educação, quando para a importância da inserção dos periódicos analisados no cenário editorial nacional e internacional.

\subsection{Formação de Professores para EJA como descritor de maior recorrência: uma análise das produções}

As discussões em torno da necessidade de formação de professores para atuar na EJA são recorrentes (MESSINA, 2002; MACHADO, 2009; INFANTE, 2010). As diversas experiências realizadas na EJA, seja por meio da escolarização institucional, seja no campo da educação popular, têm solicitado o perfil de um profissional do ensino, ora compreendido como educador ora como professor, que desenvolva o trabalho pedagógico primordialmente a partir de uma "base teórica sólida sobre as teorias pedagógicas" (ARROYO, 2006, p.26) que possibilite através delas uma compreensão mais ampla o processo de educação de adultos, de suas singularidades e particularidades.

Após análise do quantitativo de produções constantes nos dois periódicos, observamos que a temática da formação de professores para atuar na EJA continua em pauta, se apresentando como a mais recorrente, sendo debatida em maior frequência em produções divulgadas na revista Práxis Educacional com sete pesquisas e na revista Tempos e Espaços em Educação com uma produção.

O trabalho publicado na Revista Tempos e Espaços em Educação, intitulado "A Pedagogia Intercultural na Formação Docente para Educação de Jovens e Adultos - Compromisso Social das IES no Brasil" (ALMEIDA, 2012) apresenta os resultados obtidos em uma tese de doutorado sobre a formação docente para o professor da EJA. Através de estudo "quase experimental intra-grupal pré e pós-teste" (Ibid., p. 95), a autora apresenta inferências sobre a realização de um curso de 80h denominado: "Pedagogia Intercultural com ênfase na identidade cultural", tendo como objetivo central determinar os impactos da participação dos professores no curso. A discussão mostrou a ausência da formação docente na EJA, levando o leitor a refletir sobre a necessidade da construção de um novo olhar voltado para a formação docente, mostrando também a importância da pesquisa, no que diz respeito, ao conhecimento que os professores participantes, demonstraram ter sobre 
formação intercultural com ênfase na identidade cultural e nas questões de currículo ${ }^{7}$. A autora destaca em sua pesquisa que "a carência de formação docente para a EJA, sendo ela formação inicial ou continuada". (Ibid., p.103).

O tema da formação de professores para EJA localiza-se mais expressivo na revista Práxis Educacional. O artigo "Formação continuada com professoras alfabetizadoras de jovens e adultos: uma experiência para ser compartilhada" (LEGEMANN e SCHWARTZ, 2016) parte de um relato de experiência que problematiza a ausência da formação continuada para professores alfabetizadores da Educação de Jovens e Adultos, destacando a necessidade da formação continuada nessa modalidade de ensino. Na pesquisa as autoras mostram dados de um projeto de intervenção de abordagem qualitativa interventiva, aplicado na Rede Pública de Educação de Pelotas- RS, com a realização de quatro encontros quinzenais, onde foi construído um espaço para compartilhamento de saberes com o objetivo de realizar uma análise coletiva das intervenções didáticas que estavam sendo desenvolvidas pelas professoras. Ao socializar, analisar e compreender as práticas alfabetizadoras dos grupos, as autoras descreveram que "foi possível ir percebendo ao longo do estudo e da interação como grupo, que a constituição desse estudo contribuiu para mudanças na abordagem pedagógica utilizada nas salas de aula" (Ibid., p.218). O artigo, embora mostre o déficit na qualificação e formação de professores da EJA problematizando a necessidade de formação continuada para os professores da EJA, não aponta estratégias téorico-metodológicas que possa reverter esse quadro e não dialoga com autores que discorrem sobre a formação docente e formação continuada para EJA.

No texto “Especialização PROEJA CEFET/IFRN: Análise comparativa dos TCC", os autores apresentam um relato de experiência sobre uma análise documental feita em trabalhos de conclusão de curso - TCC, apresentados no Centro Federal de Educação Tecnológica do Rio Grande do Norte /Instituto Federal do Rio grande do Norte - IFRN, no curso de especialização PROEJA. A pesquisa tem como foco analisar a pertinência dos trabalhos de TCC da especialização PROEJA CEFET-RN/IFRN para a temática Educação Profissional e Educação Profissional Integrada à Educação Básica na Modalidade Educação de Jovens e Adultos - PROEJA (DE MORAIS E HENRIQUE 2018) . De acordo com os dados coletados, os autores apontam que:

Apesar das lacunas para materialização da temática do Proeja nos trabalhos de final de curso dos alunos, não se pode negar a contribuição desses TCCs para a ampliação

7 Sobre essas discussões ler os trabalhos de Pacheco e Sousa (2016), Moreira e Silva Junior (2016), Kovacs e Tinoca (2017), Ramos (2012), Sousa (2016), Pedro (2017), Dias e Menezes (2017). 
da produção de conhecimento, mesmo que tenha sido majoritariamente no campo da EJA e, de forma mais tímida, no campo do Proeja. (Ibidem., p. 382).

A pesquisa apresenta uma problematização necessária e interessante sobre o PROEJA, onde os TCC's analisados mostraram a necessidade de aprofundamento, dado à relevância que o estudo tinha nesse novo campo saberes (p. 375). Os resultados obtidos pelos pesquisadores, apontam que os TCC's não estabeleciam relações com o campo de produção de conhecimento da Educação Profissional e tão pouco do PROEJA, onde a maior parte das discussões levantadas na pesquisa, faziam referencia exclusivamente ao campo da EJA. Embora no resumo seja mencionado pelos autores que na pesquisa recorreram aos dispositivos legais do PROEJA e da formação de professores para esse campo de atuação, não foram encontrados no texto menção sobre estes.

No artigo "Formação docente, práxis pedagógica no contexto midiático da EJA" observamos discussões sobre a formação docente na EJA pautadas em temáticas reportadas à responsabilização das universidades, face às mudanças no contexto midiático, orientando assim, que as instituições de Ensino Superior dispusesse de uma práxis diferenciada para formação docente dos educadores da EJA. O texto trata da relação entre formação docente e práticas pedagógicas no contexto midiático no campo da EJA. Oliveira e Dantas (2018), expõem "a necessidade de uma formação específica para os docentes que atuam na EJA, que contribua para uma (re) significação dos conhecimentos e saberes, uma reflexão sobre a prática, antenada com as formas de comunicação da modernidade, sem menosprezar a construção de formas outras de subjetividades" (p. 11). Assim, o artigo reflete ao leitor que a formação docente para os educadores da EJA deve pautar-se em práticas pedagógicas que estejam intrinsecamente relacionadas com os interesses e demandas que a modalidade EJA exige.

Joaquim e Pesce (2018), também apresenta um estudo sobre a importância dos recursos midiáticos na formação docente, onde discutem a necessidade de uma formação docente voltada para o uso das tecnologias digitais da informação e da comunicação - TDIC nessa área da educação. Os autores assinalam que a apropriação das TDIC por parte dos docentes da EJA possibilita uma práxis que transmite o conhecimento pautado na transformação social e emancipação dos sujeitos.

Destacam que a formação docente para a EJA permite compreender melhor a modalidade, levando em consideração que esta é um direito conquistado e esta não deve ser vista apenas como uma educação compensatória, destacando ainda a necessidade de compreender que "é preciso refletir criticamente sobre o lugar das TDIC na formação de pessoas adultas, com o objetivo de 
promover a consciência crítica e a efetiva conquista da cidadania destes sujeitos" (JOAQUIM e PESCE, 2018, p. 129).

Ao refletir sobre formação docente na EJA, os autores Mauricio, Martins e Martins (2019), realizam uma discussão a partir do levantamento de trabalhos no banco de dissertações e teses da CAPES entre os anos de 2015 e 2016. Com o estudo, os autores concluíram que a formação de professores destinada a EJA no Brasil é uma área incipiente em todos os seus aspectos, seja na construção de políticas públicas, nas pesquisas acadêmicas e principalmente nos cursos de licenciatura das Universidades Brasileiras.

De igual modo, o texto "O Estado do Conhecimento: A Dialogicidade entre a Educação Inclusiva e a Educação de Jovens e Adultos" de Miron e Schardosim (2020) apresenta um inventário dos trabalhos publicados na biblioteca virtual nacional da Associação Nacional de Pós-Graduação e Pesquisa em Educação (ANPEd) que tratam da Educação Inclusiva dentro Educação de Jovens e Adultos (EJA) em um recorte temporal do ano de 2005 a 2017. O trabalho revela que "apesar da relevância dos artigos analisados, ainda há muitas lacunas dentro da reflexão dessa temática" (Ibidem. p. 592): estudos que dialoguem sobre a formação de professores para atuarem na perspectiva inclusiva na EJA.

Em suma, ao analisar as publicações nos últimos dez anos, foram encontradas diversas pesquisas que trazem grandes contribuições ao campo da formação de professores para EJA. Entretanto, todos os trabalhos apresentam convergência para o fato que as lacunas na formação de implicam na ausência de reconhecimento das especificidades e peculiaridades dos sujeitos que demandam essa oferta educativa.

\section{CONSIDERAÇÕES FINAIS}

Este estudo teve como objetivo analisar a produção de artigos científicos que abordam a temática Educação de Jovens e Adultos em duas revistas nacionais, a Revista Tempos e Espaços em Educação e a Revista Práxis Educacional, buscando compreender como estão sistematizadas as produções sobre essa área da educação nos dois periódicos.

No primeiro momento apresentamos uma reflexão sobre a expansão das pesquisas nesse campo da educação, identificando a multidimensionalidade das práticas e o alargamento do campo teórico que orbita em torno dos estudos em EJA, o que pudemos observar mais substancialmente ao inventariar as produções. 
Assim, foram encontradas nas duas revistas um total de 45 produções, sendo que a maior recorrência das publicações se concentraram na temática formação de professores para EJA, com 13 artigos. Diante disso, nos debruçamos em apresentar um maior detalhamento e análise dessas produções, identificando que a temática sobre a formação de professores continua sendo um grande entrave para essa área da educação, ocorrência que já vem sendo amplamente discutida na literatura das pesquisas sobre a EJA.

Por fim, consideramos que o número de artigos encontrados é bastante significativo, mas não suficiente, uma vez que a Educação de Jovens e Adultos é uma área da educação que ainda encontra-se limitada a uma visão compensatória, necessitando avançar para consolidação de um campo pedagógico próprio, reconhecendo as especificidades da área e as peculiaridades dos seus sujeitos.

\section{REFERÊNCIAS}

ALMEIDA, M. J. DE M. A Pedagogia Intercultural na Formação Docente para Educação de Jovens e Adultos - Compromisso Social das IES no Brasil. Revista Tempos e Espaços em Educação, v. 11. n. 22 p. 114-134, DOI: https://doi.org/10.20952/revtee.v0i0.2289. Disponível em: https://seer.ufs.br/index.php/revtee/article/view/2289 . Acesso em: 01 set. 2020.

ALVES, J. L.; CÂNCIO, D. de O. Alfabetização de adultos: uma ferramenta para a sustentabilidade. Revista Práxis Educacional, [S. I.], v. 12, n. 21, p. 231-246, 2015. Disponível em: http://periodicos2.uesb.br/index.php/praxis/article/view/869. Acesso em: 14 jul 2020.

AMADO, João da Silva. Construir a disciplina para um ensino de qualidade. Revista Práxis Educacional, Vitória da Conquista, v.4, n. 5, jun./dez. 2008. Disponível em: http://periodicos2.uesb.br/index.php/praxis/article/view/574. Acesso em: 12 fev. 2020.

ARAÚJO, G. C. de; MIGUEL, J. C.; SILVA, E. M. da. The aesthetical literacy in the consolidation of reading and writing of Young and Adult Peasants. Revista Práxis Educacional, v. 15, n. 35, p. 246272, 2019. DOI: 10.22481/praxisedu.v15i35.5703. Disponível em:

http://periodicos2.uesb.br/index.php/praxis/article/view/5703. Acesso em: 21 jun. 2020.

ARROYO, Miguel. "Formar educadoras e educadores de Jovens e Adultos". IN: SOARES, Leôncio José (org.). Formação de educadores de Jovens e Adultos. Belo Horizonte: Autêntica/SECADMEC/UNESCO, 2006.

ASSOLINI, Filomena Elaine Paiva. Professoras alfabetizadoras e suas leituras: história, memória e prática pedagógica escolar. Revista Práxis Educacional, Vitória da Conquista, v. 6, n. 8, jan./jun. 2010. Disponível em: http://periodicos2.uesb.br/index.php/praxis/article/view/616. Acesso em: 14 fev. 2020. 
BARBOSA, S. D. P.; QUIRINO, R. A Educação Profissional de Jovens em Privação de Liberdade. Revista Práxis Educacional, [S. I.], v. 16, n. 37, p. 465-482, 2020. DOI:

10.22481/praxisedu.v16i37.6210. Disponível em:

http://periodicos2.uesb.br/index.php/praxis/article/view/6210. Acesso em: 5 out. 2020.

BRITO, Regivane dos Santos; PRADO, Jany Rodrigues; NUNES, Claudio Pinto. As condições de trabalho docente e o pós-estado de bem-estar social. Revista Tempos e Espaços em Educação (online), v. 10, p. 165-174, 2017. Disponível em:

https://seer.ufs.br/index.php/revtee/article/view/6676. Acesso em: 28 mar. 2020.

COSTA, Ana Sheila Fernandes; AKKARI, Abdeljalil; SILVA, Rossana Valéria Souza. Educação básica no Brasil: políticas públicas e qualidade. Revista Práxis Educacional, Vitória da Conquista, v.7, n. 11, jun./dez. 2011. Disponível em: http://periodicos2.uesb.br/index.php/praxis/article/view/666. Acesso em: 14 fev. 2020.

COSTA SANTOS DA PAIXÃO, M.; BRUNO ARAÚJO QUEIROZ, M.; ANDRÉA VIANNA PRUDÊNCIO, C. As experiências dos licenciandos em ciências biológicas com a Educação de Jovens e Adultos. Revista Práxis Educacional, v. 15, n. 32, p. 274-296, 2019. DOI: 10.22481/praxis.v15i32.5055. Disponível em: http://periodicos2.uesb.br/index.php/praxis/article/view/5055. Acesso em: 05 jun. 2020.

COUCEIRO FIGUEIRA, A. P. (In)congruências na orientação metodológica dos professores: análise nas dimensões da prática educativa (resultados comparativos numa amostra de professores de português, matemática e inglês). Revista Práxis Educacional, , v. 5, n. 7, p. 165-200, 2010. Disponível em: http://periodicos2.uesb.br/index.php/praxis/article/view/608. Acesso em: 04 jun. 2020.

CUNHA, Úrsula Nascimento de Sousa. Leitura e escrita no ensino fundamental, (res) significando o trabalho com gêneros textuais. Revista Práxis Educacional, Vitória da Conquista, v.6, n. 8, jan./jun. 2010. Disponível em: http://periodicos2.uesb.br/index.php/praxis/article/view/621. Acesso em: 15 fev. 2020.

DE BRITO SIMÕES DOS SANTOS, M. R. O desafio das novas oportunidades educativas em Portugal. Revista Práxis Educacional, [S. I.], v. 5, n. 7, p. 73-95, 2010. Disponível em: <http://periodicos2.uesb.br/index.php/praxis/article/view/602> Acesso em: 04 out. 2020.

DA SILVA DE FARIA, E. M. O percurso formativo dos professores/pesquisadores da EJA na contemporaneidade. Revista Práxis Educacional, [S. I.], v. 5, n. 7, p. 151-164, 2009. Disponível em: http://periodicos2.uesb.br/index.php/praxis/article/view/607. Acesso em: 4 out. 2020.

DE MELLO, F. M.; MOREIRA, J. dos S. A experiência de alfabetização de jovens e adultos do programa Re-aprender no conjunto penal de Jequié-Bahia. Revista Práxis Educacional, v. 5, n. 7, p. 207-216, 2010. Disponível em: http://periodicos2.uesb.br/index.php/praxis/article/view/610. Acesso em: 09 set 2020

DE MORAIS, J. K. C.; HENRIQUE, A. L. S. Especialização PROEJA CFET/IFRN: Análise Comparativa dos TCC. Revista Práxis Educacional, v. 14, n. 27, 2018. DOI: 10.22481/praxis.v14i27.2931. Disponível em: http://periodicos2.uesb.br/index.php/praxis/article/view/2931 . Acesso em: 20 set. 2020. 
DIAS, Alfrancio Ferreira; MENEZES, Carlos André Araújo. Que inovação pedagógica a pedagogia queer propõe ao currículo escolar?. Revista Tempos e Espaços em Educação, São Cristóvão - SE, v. 10, n. 23, p. 37-48, 2017. Disponível em: https://seer.ufs.br/index.php/revtee/article/view/7443. Acesso em: 07 jul. 2020. DOI: https://doi.org/10.20952/revtee.v10i23.7443.

DUARTE, Alexandre William Barbosa; OLIVEIRA, Dalila Andrade. Valorização profissional docente nos sistemas de ensino de Minas Gerais e Pernambuco. Revista Práxis Educacional, Vitória da Conquista, v.10, n. 17, jun./dez. 2014. Disponível em: http://periodicos2.uesb.br/index.php/praxis/article/view/780. Acesso em: 12 fev. 2020.

EUGÊNIO, Benedito Gonçalves. O currículo na educação de jovens e adultos: entre o formal e o cotidiano numa escola municipal em belo horizonte. Revista Práxis Educacional, Vitória da Conquista, v. 4, n. 4, jan./jun. 2008. Disponível em: https://periodicos2.uesb.br/index.php/praxis/article/view/570. Acesso em: 19 abr. 2020.

FARIA, Edite Maria da Silva de. O percurso formativo dos professores/pesquisadores da EJA na contemporaneidade. Revista Práxis Educacional, Vitória da Conquista, v. 5, n. 7, jan./jun. 2009. Disponível em: http://periodicos2.uesb.br/index.php/praxis/article/view/607. Acesso em: $10 \mathrm{fev}$. 2020.

FREIRA, Maria Auxiliadora S. Práxis pedagógica e professores intelectuais: refletindo as tensões e concepções da formação/prática docente. Revista Práxis Educacional, Vitória da Conquista, v.1, n. 1, jan./dez. 2005. Disponível em: http://periodicos2.uesb.br/index.php/praxis/article/view/485. Acesso em: 23 mar. 2020.

FREITAS, M. L. de Q.; DA SILVA, J. C. Trilhas da história oral: Memórias da Educação de Jovens e Adultos em Alagoas. Revista Práxis Educacional, v. 15, n. 33, p. 255-277, 2019. DOI: 10.22481/praxisedu.v15i33.5286 Disponível em: http://periodicos2.uesb.br/index.php/praxis/article/view/5286. Acesso em: 5 out. 2020.

FURTADO SALES, S. C.; COTRIM COSTA, G. A.; OLIVEIRA, J. P. A trajetória da EJA no estado da Bahia: da suplência à aceleração. Práxis Educacional, [S. I.], v. 5, n. 7, p. 115-128, 2010. Disponível em: <http://periodicos2.uesb.br/index.php/praxis/article/view/605.> Acesso em: 07 jul. 2020.

HADDAD, S. O estado da arte das pesquisas em educação de jovens e adultos no Brasil: a produção discente da pós-graduação em educação no período 1986-1998. São Paulo: Ação Educativa, 2000.

ILHA, Franciele Roos da Silva; HYPOLITO, Álvaro Moreira. O trabalho docente no início da carreira e sua contribuição para o desenvolvimento profissional do professor. Revista Práxis Educacional, Vitória da Conquista, v.10, n. 17, jun./dez. 2014. Disponível em: http://periodicos2.uesb.br/index.php/praxis/article/view/781. Acesso em: 11 fev. 2020.

IWAMOTO, H. M. A educação matemática de jovens e adultos no ensino superior de administração: relato de experiências na Universidade Federal do Tocantins. Revista Práxis Educacional, [S. I.], v. 5, n. 7, p. 201-206, 2010. Disponível em:

http://periodicos2.uesb.br/index.php/praxis/article/view/609. Acesso em: 04 set. 2020. 
JOAQUIM, B. dos S.; PESCE, L. O uso (crítico) das Tecnologias Digitais da Informação e da Comunicação na Educação (não compensatória) de Jovens e Adultos. Revista Práxis Educacional, v. 14, n. 29, p. 126-142, 2018. DOI: 10.22481/praxis.v14i29.4102. Disponível em: http://periodicos2.uesb.br/index.php/praxis/article/view/4102. Acesso em: 30 ago. 2020.

KOVACS, Helena; TINOCA, Luís. Unfreeze the pedagogies: introduction of a new innovative measure in Portugal. Revista Tempos e Espaços em Educação, São Cristóvão - SE, v. 10, n. 23, p. 73-86, 2017. Disponível em: https://seer.ufs.br/index.php/revtee/article/view/7446/pdf. Acesso em: 07 jul. 2020. DOI: https://doi.org/10.20952/revtee.v10i23.7446

LEITE, M. I. P. A.; SANTOS, José Jackson Reis dos. Investigação-ação na formação de profissionais pesquisadores(as): uma experiência no ciclo de aprendizagem e na educação de pessoas jovens e adultas. Revista Práxis Educacional, v. 2, n. 2, p. 79-95, 2017. Disponível em: <http://periodicos2.uesb.br/index.php/praxis/article/view/514> . Acesso em: 04 jul. 2020.

LEGEMANN OLIVEIRA, M. P.; SCHWARTZ, S. Formação continuada com professoras alfabetizadoras de jovens e adultos: uma experiência para ser compartilhada. Revista Práxis Educacional, v. 12, n. 23, p. 199-222, 2015. Disponível em:

<http://periodicos2.uesb.br/index.php/praxis/article/view/912.> Acesso em: 12 ago. 2020.

LEITE, I. Desafíos del siglo XXI para la Educación Popular: nuevos fundamentos para nuevas prácticas. Revista Tempos e Espaços em Educação, v. 13, n. 32, p. 1-20, 2020.

DOI: https://doi.org/10.20952/revtee.v13i32.13646. Disponível em:

https://seer.ufs.br/index.php/revtee/article/view/13646. Acesso em: 14 ago. 2020.

MACHADO, Maria Margarida. Especificidades da formação de professores para ensinar jovens e adultos. In: LISITA, Verbena Moreira Soares de Sousa; PEIXOTO, Adão José. (org.) Formação de Professores - políticas, concepções e perspectivas. 1.ed., Goiânia: Editora Alternativa, p.24, 2001.

MARQUES JARDIM, S. R.; COSTA, S. A. Educação do campo: alfabetização e escolarização de pessoas jovens e adultas assentadas no sudoeste da Bahia. Revista Práxis Educacional, [S. I.], v. 2, n. 2, p. 171-183, 2010. Disponível em:

<http://periodicos2.uesb.br/index.php/praxis/article/view/519.> Acesso em: 4 jul. 2020.

MAURICIO, S. S.; JUNIOR, L. M.; MARTINS, R. E. M. W. Para Pensar e Movimentar a Formação Docente na EJA: Um Mapeamento das Produções Acadêmicas Entre o Período 2015-2016. Revista Práxis Educacional, v. 15, n. 33, p. 555-573, 2019. DOI: 10.22481/praxisedu.v15i33.5305. Disponível em: <http://periodicos2.uesb.br/index.php/praxis/article/view/5305.> Acesso em: 31 ago. 2020.

MESSINA, Graciela. La formación de los educadores de las personas jóvenes y adultas: El camino de la reflexión desde la práctica. Santiago: Cátedra Jaime Torres Bodet, 2002.

MILLS, Charles Wright. A Imaginação Sociológica. Rio de Janeiro: Zahar, 1982.

MIRANDA, M. L. F.; VASCONCELOS, C. F. C.; JUSTI, J. Prática pedagógica docente na educação de jovens e adultos privados de liberdade pertencentes a uma unidade prisional. Revista Tempos e Espaços em Educação, v. 12, n. 29, p. 103-124, 2019. 
DOI: https://doi.org/10.20952/revtee.v12i29.9146. Disponível em:

https://seer.ufs.br/index.php/revtee/article/view/9146 . Acesso em: 10 set. 2020.

MIRON, K. T. S.; SCHARDOSIM, C. R. Estado do Conhecimento: A Dialogicidade Entre a Educação Inclusiva e a Educação de Jovens e Adultos. Revista Práxis Educacional, v. 16, n. 40, p. 592-611, 2020. DOI: 10.22481/praxisedu.v16i40.6580. Disponível em:

http://periodicos2.uesb.br/index.php/praxis/article/view/6580. Acesso em: 31 ago. 2020.

MOURA, Tania Maria de Melo. Formação de educadores de jovens e adultos: realidade, desafios e perspectivas atuais. Revista Práxis Educacional, Vitória da Conquista, v.5, n. 7, jul./dez. 2009. Disponível em: http://periodicos2.uesb.br/index.php/praxis/article/view/601. Acesso em: 22 de março de 2019.

MOURA, M. da G. C.; MELO, B. M. da S. Prevenção ao uso de drogas na Educação de Jovens e Adultos:: Diálogo com o campo de pesquisa. Revista Práxis Educacional, v. 14, n. 29, p. 106-125, 2018. DOI: 10.22481/praxis.v14i29.4101. Disponível em:

http://periodicos2.uesb.br/index.php/praxis/article/view/4101. Acesso em: 05 set. 2020.

MOREIRA, Antonio Flávio; SILVA JÚNIOR, Paulo Melgaço da. Currículo, Transgressão e Diálogo: quando Outras Possibilidades se Tornam Necessárias. Revista Tempos e Espaços em Educação, São Cristóvão - SE, v. 9, n. 18, p. 45-54, 2016. Disponível em:

https://seer.ufs.br/index.php/revtee/article/view/4962/4097. Acesso em: 07 jul. 2020.

DOI: https://doi.org/10.20952/revtee.v9i18.4962.

NASCIMENTO, L. F.; CAVALCANTE, M. M. D. Abordagem quantitativa na pesquisa em educação: investigações no cotidiano escolar. Revista Tempos e Espaços em Educação, v. 11, n. 25, p. 249260, 29 mar. 2018. Disponível em: https://seer.ufs.br/index.php/revtee/article/view/7075 Doi: https://doi.org/10.20952/revtee.v11i25.7075

NETO, J. C. DA S.; ANDRADE, M. C. N. Os jovens e os adultos que fogem da escola. A escola que expulsa os jovens e os adultos: reflexões sobre o abandono na EJA. Revista Tempos e Espaços em Educação, v. 11, n. 24, p. 124-142, 2010. DOI: https://doi.org/10.20952/revtee.v0i0.2237. Disponível em: https://seer.ufs.br/index.php/revtee/article/view/2237 Acesso em: 07 ago. 2020.

NUNES, Claudio Pinto. Formación y trabajo docente: cuestiones contemporáneas. Revista Êxitus, Santarém, v. 9, n. 1, 2019. Disponível em:

http://www.ufopa.edu.br/portaldeperiodicos/index.php/revistaexitus/article/view/917. Acesso em: 07 abr. 2020.

NUNES, Claudio Pinto; OLIVEIRA, Dalila Andrade. Trabalho, carreira, desenvolvimento docente e mudança na prática educativa. Educação e Pesquisa, São Paulo, v. 43, p. 65-80, 2017. Disponível em: https://www.scielo.br/scielo.php?pid=S1517-

97022017000100066\&script=sci abstract\&tlng=pt. Acesso em: 23 abr. 2020.

OLIVEIRA, M. O. de M.; DANTAS, T. R. Formação Docente, Práxis Pedagógica no Contexto Midiático da EJA. Revista Práxis Educacional, v. 14, n. 29, p. 35-49, 2018. DOI:

10.22481/praxis.v14i29.4095. Disponível em:

http://periodicos2.uesb.br/index.php/praxis/article/view/4095. Acesso em: 31 ago. 2020. 
OLIVEIRA, S. S. de; OLIVEIRA, I. A. de. Educação de Jovens e Adultos no Sistema Prisional: Reinserção social de Mulheres. Revista Práxis Educacional, v. 14, n. 29, p. 88-105, 2018. DOI: 10.22481/praxis.v14i29.4100. Disponível em: http://periodicos2.uesb.br/index.php/praxis/article/view/4100 http://10.22481/praxis.v14i29.4100Acesso em: 12 jul. 2020.

PARASKEVA, J. M. "Brutti, Sporchi \& Cattivi": Towards a Non-Abyssal Curriculum. Revista Tempos e Espaços em Educação, v. 9, n. 18, p. 75-90, 2016. Disponível em: https://seer.ufs.br/index.php/revtee/article/view/4966 Doi: https://doi.org/10.20952/revtee.v9i18.4966

PACHECO, José Augusto; SOUSA, Joana. O (pós) crítico na Desconstrução Curricular. Revista Tempos e Espaços em Educação, v. 9, n. 18, p. 65-74, 2016. Disponível em: https://seer.ufs.br/index.php/revtee/article/view/4971/4105. Acesso em: 07 jul. de 2020. DOI: https://doi.org/10.20952/revtee.v9i18.4971.

PAULA, R. da S. O não-lugar da pessoa idosa na educação. Revista Práxis Educacional, v. 5, n. 7, p. 29-43, 2010. Disponível em: <http://periodicos2.uesb.br/index.php/praxis/article/view/604.> Acesso em: 4 out. 2020. DOI:

PEREIRA, A. A Educação de Jovens e Adultos no Sistema Prisional Brasileiro: O Que Dizem os Planos Estaduais de Educação em Prisões?. Revista Tempos e Espaços em Educação, v. 11, n. 24, p. 245-252, 2018. DOI: https://doi.org/10.20952/revtee.v11i24.6657. Disponível em: https://seer.ufs.br/index.php/revtee/article/view/6657 . Acesso: 14 ago. 2020.

PEREIRA, A. Os sujeitos da EJA e da Educação Social: As pessoas em situação de Vulnerabilidade Social. Revista Práxis Educacional, v. 15, n. 31, p. 273-294, 2019. DOI:

10.22481/praxis.v15i31.4673. Disponível em:

http://periodicos2.uesb.br/index.php/praxis/article/view/4673. Acesso em: 15 jun. 2020.

PEREZ, Marcia Cristina Argenti. Infância e escolarização: discutindo a relação família, escola e as especificidades da infância na escola. Revista Práxis Educacional, Vitória da Conquista, v. 8, n. 12, jan./jun. 2012. Disponível em: http://periodicos2.uesb.br/index.php/praxis/article/view/684. Acesso em: 15 fev. 2020.

PEDRO, Neuza. Ambientes educativos inovadores: o estudo do fator espaço nas 'salas de aula do futuro' portuguesas. Revista Tempos e Espaços em Educação, São Cristóvão - SE, v. 10, n. 23, p. 99-108, 2017. Disponível em: https://seer.ufs.br/index.php/revtee/article/view/7448. Acesso em: 07 jul. de 2020. DOI: https://doi.org/10.20952/revtee.v10i23.7448.

RAMOS, M. DA C. P. Ambiente, Educação e Interculturalidade. Revista Tempos e Espaços em Educação, v. 5, n. 8, jan./jan., 2012. Disponível em:

https://seer.ufs.br/index.php/revtee/article/view/2284

REBELO, P. V.; BORGES, G. F. Contributos para o estudo do desenvolvimento do adulto: reflexões em torno da generatividade. Revista Práxis Educacional, v. 5, n. 7, p. 97-114, 2010. Disponível em: http://periodicos2.uesb.br/index.php/praxis/article/view/603. Acesso em: 03 jul. 2020. 
REZENDE, V. A. A Dimensão Ambiental na Educação de Jovens e Adultos: Possibilidades e Desafios. Revista Tempos e Espaços em Educação, v. 6 n. 11 p. 67-76, 2013.

DOI: https://doi.org/10.20952/revtee.v0i0.2542. Disponível em:

https://seer.ufs.br/index.php/revtee/article/view/2542. Acesso: 08 set. 2020.

RIBEIRO, I.; LAFFIN, M. H. L. F.; AGUIAR, P. A. DE. Reflexões Sobre Formação de Formadores Para o Proeja: O Caso do Instituto Federal de Santa Catarina. Revista Tempos e Espaços em Educação, v. 12, n. 29, p. 41-60, 2019. DOI: https://doi.org/10.20952/revtee.v12i29.8982. Disponível em: https://seer.ufs.br/index.php/revtee/article/view/8982. Acesso: 08 set. 2020.

ROSSEL, N. C. Por la defensa del derecho a la Educación de los Jóvenes y Adultos en América Latina y el Caribe. Revista Práxis Educacional, [S. I.], v. 14, n. 29, p. 50-65, 2018. DOI:

10.22481/praxis.v14i29.4097. Disponível em:

http://periodicos2.uesb.br/index.php/praxis/article/view/4097. Acesso em: 17 set. 2020.

SAMPAIO, M. N. Educação de Jovens e Adultos: uma história de complexidade e tensões. Revista Práxis Educacional, [S. I.], v. 5, n. 7, p. 13-27, 2009. Disponível em:

<http://periodicos2.uesb.br/index.php/praxis/article/view/600>. Acesso em: 07 ago 2020.

SANTOS, José Jackson Reis dos. Especificidades dos saberes para a docência na educação de pessoas jovens e adultas. Revista Práxis Educacional, Vitória da Conquista, v.6, n. 8, jan./mar. 2010. Disponível em: http://periodicos2.uesb.br/index.php/praxis/article/view/623. Acesso em: 22 de março de 2019.

SANTOS, José Jacson Reis dos. Práticas pedagógicas crítico emancipatórias: em educação de pessoas jovens, adultas e idosas. Revista Práxis Educacional, v. 3, n. 3, p. 335-336, 2017.

Disponível em: http://periodicos2.uesb.br/index.php/praxis/article/view/547. Acesso em: 07 set. 2020.

SANTOS, José Jacson Reis dos. Saberes necessários para a docência na educação de jovens e adultos. Revista Práxis Educacional, v. 7, n. 11, p. 243-244, 2012. Disponível em:

http://periodicos2.uesb.br/index.php/praxis/article/view/677. Acesso em: 19 jul 2020.

SANTOS PEREIRA, J. D. Concepções e práticas de escrita numa classe de alfabetização de jovens e adultos. Revista Práxis Educacional, v. 4, n. 4, p. 123-144, 2008. Disponível em:

http://periodicos2.uesb.br/index.php/praxis/article/view/564. Acesso em: 08 set. 2020.

SILVA, Daniela Oliveira Vidal da; BRITO, Vera Lúcia Fernandes de; NUNES, Claudio Pinto. Valorização docente na conjuntura do pós impeachement de 2016 no Brasil. Revista Cocar (online), v. 13, p. 1-20, maio/ago. 2019. Disponível em:

https://periodicos.uepa.br/index.php/cocar/article/view/2518. Acesso em: 19 fev. 2020.

SILVA, D. V. Entre o ser e o ter: Dilemas e sentidos da Educação de Adultos. Revista Práxis

Educacional, v. 14, n. 29, p. 17-34, 2018. DOI: 10.22481/praxis.v14i29.4094. Disponível em: http://periodicos2.uesb.br/index.php/praxis/article/view/4094. Acesso em: 18 jul. 2020.

SILVEIRA, M. M.; DE SANTANA, J. S.; COSTA, E. F. X. Saberes Pedagógicos na Educação de Jovens e Adultos. Revista Tempos e Espaços em Educação, p. 47-56, v. 6 n. 11. 
DOI: https://doi.org/10.20952/revtee.v0i0.2540. Disponível em:

https://seer.ufs.br/index.php/revtee/article/view/2540 . Acesso em: 08 set. 2020.

SOBRAL, M. N. Educação e formação de adultos: políticas, práticas e investigação. Revista Práxis Educacional, v. 9, n. 14, p. 189-194, 2013. Disponível em:

http://periodicos2.uesb.br/index.php/praxis/article/view/737. Acesso em: 24 ago 2020.

SOBRINHO, Roberto Sanches Mubarac. As culturas infantis indígenas e os saberes da escola: uma prática pedagógica dos (des)encontros. Revista Práxis Educacional, Vitória da Conquista, v. 6, n. 8, jan./jun. 2010. Disponível em: http://periodicos2.uesb.br/index.php/praxis/article/view/622. Acesso em: 14 fev. 2020.

SOUSA, Jesus Maria. Repensar o currículo como emancipador. Revista Tempos e Espaços em Educação, São Cristóvão - SE, v. 9, n. 18, p. 111-120, 2016. Disponível em:

https://seer.ufs.br/index.php/revtee/article/view/4969. Acesso em: 07 jul. 2020. DOI:

https://doi.org/10.20952/revtee.v9i18.4969.

TEIXEIRA, Célia. Regina. O "estado da arte": a concepção de avaliação educacional veiculada na produção acadêmica do programa de pós-graduação em educação: currículo (1975- 2000).

Cadernos de Pós-Graduação: educação, v. 5 n. 1, p. 59-66, 2006. Disponível em:

https://periodicos.uninove.br/index.php?journal=cadernosdepos\&page=article\&op=view\&path\%5 B\%5D=1845. Acesso em: 10 set. 2020.

TEIXEIRA, Eliara Cristina Nogueira; NUNES, Claudio Pinto. A valorização docente e a lei do piso salarial: um estado da arte. Educação e Cultura Contemporânea, v. 16, p. 437-452, 2019. Disponível em: http://periodicos.estacio.br/index.php/reeduc/article/view/1886. Acesso em: 12 abr. 2020.

TEIXEIRA, Eliara Cristina Nogueira; NUNES, Claudio Pinto. O Piso Salarial Nacional no Contexto do Financiamento da Educação no Brasil: limites e possibilidades do seu cumprimento. FINEDUCA: Revista de Financiamento da Educação. v. 9, p. 1-17, 2019. Disponível em: https://seer.ufrgs.br/fineduca/article/view/90205. Acesso em: 02 abr. 2020.

TEIXEIRA, Eliara Cristina Nogueira; NUNES, Claudio Pinto. Os sentidos atribuídos ao piso salarial nacional como política pública de valorização docente. Revista Tempos e Espaços em Educação, Aracaju, v. 12, n. 29, p. 195-212, 2019. Disponível em:

https://seer.ufs.br/index.php/revtee/article/view/10688. Acesso em: 14 mar. 2020.

VALENTIM, S. dos S.; ASSIS, N. P. de. Juventude negra e Educação de Jovens e Adultos (EJA): Reflexões na perspectiva da teoria da resiliência. Revista Práxis Educacional, v. 14, n. 29, p. 66-87, 2018. DOI: 10.22481/praxis.v14i29.4099. Disponível em:

http://periodicos2.uesb.br/index.php/praxis/article/view/4099. Acesso em: 4 out. 2020.

VENÂNCIO, J. C.; GARBOGGINI DI GIORGI, C. A. As séries iniciais da Educação de Jovens e Adultos em nível municipal e as políticas públicas implementadas - em busca de novos significados. Revista Práxis Educacional, v. 5, n. 7, p. 129-150, 2009. Disponível em:

<http://periodicos2.uesb.br/index.php/praxis/article/view/606.> Acesso em: 23 ago. 2020. 


\section{SOBRE OS AUTORES}

\section{Adenilson Souza Cunha Júnior}

Professor Adjunto do Departamento de Ciências Humanas, Educação e Linguagem e do Programa de Pós-graduação em Educação da Universidade Estadual do Sudoeste da Bahia (UESB). Licenciado em Pedagogia (UESB), Mestre (UFS) e Doutor em Educação (UFMG).

E-mail: adenilsoncunha@uesb.edu.br

Orcid: https://orcid.org/0000-0003-3622-1799

\section{Geovânia Lúcia dos Santos}

Professora de Política Educacional e Gestão Educacional do Departamento de Ciências Humanas do Instituto de Ciências Humanas e Letras da Universidade Federal de Alfenas - UNIFAL-MG. Bacharel e Licenciada em História (1995/96), Mestre (2001) e Doutora em Educação pela UFMG (2019).

E-mail: geolusantos@hotmail.com

Orcid: http://orcid.org/0000-0002-5228-3378

\section{Marileide Moutinho Pomponet Lima}

Mestranda pelo Programa de Pós-graduação em Educação da Universidade Estadual do Sudoeste da Bahia (PPGEd-UESB).

E-mail: leidemp@hotmail.com

Orcid: http://orcid.org/0000-0002-1688-6892 